\title{
The evolution of breast implants
}

\author{
Walter Peters PhD MD FRCSC
}

\section{W Peters. The evolution of breast implants. Can J Plast Surg 2002;10(5):223-236.}

The present review traces the evolution of breast implants over the past 50 years. During the early years (from 1951 to 1962), a number of different sponges were used for breast augmentation. The first of these was Ivalon, a polyvinyl alcohol sponge. Other sponges were introduced subsequently, including Etheron (a polyether sponge popularized by Dr Paule Regnault in Montreal) and Polystan (fabric tapes that were wound into a ball). Subsequently, polyethylene strips enclosed in a fabric or polyethylene casing were also used for breast augmentation. All of these materials had similar outcomes. Although the initial results were encouraging, within one year of augmentation, breasts became very firm and lost over $25 \%$ of their volume. This was due to capsular contracture, a process that would lead to the collapse of the sponge and would continue to plague plastic surgeons and their patients for the next 50 years. In 1963, Cronin and Gerow introduced the silicone gel 'natural feel' implant, which revolutionized breast augmentation surgery. Approximately 10 companies have manufactured many types of silicone gel breast implants over the years. They obtained their raw materials for gels and shells from a similar number of other companies that entered and left the market at intervals. Many of the suppliers and manufactures changed their names and ownership over the years, and most of the companies no longer exist. No formal process of United States Food and Drug Administration premarket testing was in effect until 1988. There have been three generations of gel implants and a number of other lesser variations. First-generation implants (1963 to 1972) had a thick gel and a thick wall. They have generally remained intact over the years. Second-generation implants (1973 to the mid-1980s) had a thin gel and a thin wall. They have tended to disrupt over time. Third-generation implants (mid-1980s to 1992) had a thick wall and a thick gel. Except for those made by Surgitek, these implants remain intact. The breast implant business was competitive and companies introduced changes such as softer gels; barrier low-bleed shells; greater or lesser shell thickness; surface texturing; different sizes, contours and shapes; and multiple lumens in search of better aesthetics. Ultimately, more than 240 styles and 8300 models of silicone gel breast implants were manufactured in the United States alone. Inflatable breast implants were introduced in Toulons, France in 1965 (the Simaplast implant). There have been three main eras of inflatable implants: seamed, high-temperature vulcanized and room temperature vulcanized implants. In 1973, spontaneous deflation rates of $76 \%$ to $88 \%$ over three years were reported for many types of inflatable implants. Because of this, most plastic surgeons abandoned their use. From 1963 until the moratorium on gel implants (January 6, 1992), about 95\% of all breast implants inserted were silicone gel filled. Only 5\% were saline filled. Since the moratorium, this ratio has been reversed and $95 \%$ of all implants have been saline-filled, with only $5 \%$ being gel filled. Polyurethane-coated (PU) silicone gel implants were introduced in 1968. Over the next 20 years, they were shown to reduce the prevalence of capsular contracture to $2 \%$ to $3 \%$. Other forms of surface texturing (Biocell, Siltex, multistructured implant) also appear to reduce capsular contracture with gel implants, but the reduction has been much less dramatic than that seen with PU implants. Contoured (anatomical) shaping appears to have advantages in some patients with gel implants. No such advantage has been seen for texturing or shaping with saline-filled implants. The story of gel implants has culminated in the largest class action lawsuit in medical history, with US $\$ 4.2$ billion being awarded to women with silicone gel implants. During the past decade, there has been a tremendous amount of research on the reaction of a woman's body to gel implants. A plethora of studies have demonstrated that silicone gel implants are not associated with the development of any medical diseases. Silicone gel-filled implants have therefore been approved for use under Health Canada's Special Access Program. Silicone gelfilled implants may now be used in certain patients in whom they would provide advantages over saline implants. Silicone gel implants have not been approved for unrestricted general use. The evolution of breast implants occupies the past half century. It has been a stormy course, with many exciting advances and many bitter disappointments. The universe of breast implants is large and the variation among the implants is substantial. The purpose of the present review is to trace the evolution of breast implants over the past 50 years.

Key Words: Breast implants; Evolution

Presented in part at the 29th Annual Meeting of the Canadian Society for Aesthetic (Cosmetic) Plastic Surgery, October 5, 2002, Toronto, Ontario Division of Plastic Surgery, University of Toronto, Toronto, Ontario

Correspondence: Dr Walter Peters, Suite 802, 600 Sherbourne Street, Toronto, Ontario M4X 1W4. Telephone 416-926-7790, fax 416-926-4997, e-mail walter.peters@utoronto.ca 


\section{L'évolution des prothèses mammaires}

RÉSUMÉ : Le présent article retrace les grands faits qui ont marqué l'évolution des prothèses mammaires au cours des 50 dernières années. Au début (de 1951 à 1962), on a eu recours à différents types d'éponge pour l'augmentation mammaire. Le premier modèle a été commercialisé sous le nom d'Ivalon, éponge en poly(alcool de vinyle). D'autres types d'éponge ont été mis en marché plus tard, dont Etheron (éponge de polyéther, promotionnée par la Dre Paule Regnault, à Montréal) et Polystan (galons en croisé enroulés sous forme de balle). Ont suivi les bandes de polyéthylène contenues dans des enveloppes de tissu ou de polyéthylène. Toutefois, ces matériaux connaissaient tous le même sort : après des débuts encourageants, les seins commençaient, au cours de la première année postopératoire, à devenir très fermes et à perdre $25 \%$ de leur volume. La déformation était due à une rétraction capsulaire, processus qui menait à l'affaissement des éponges et qui allait hanter les chirurgiens plasticiens et leurs patientes durant 50 ans. En 1963, Cronin et Gerow ont lancé la prothèse de gel de silicone, d'apparence naturelle, qui a révolutionné la chirurgie d'augmentation mammaire. Une dizaine d'entreprises ont commencé à fabriquer différents types de prothèse de silicone et une dizaine d'autres, venant et passant, fournissaient la matière première pour la fabrication du gel et des enveloppes. Bon nombre de fournisseurs et de fabricants ont changé de nom et de propriété au cours des ans, et la plupart des entreprises n'existent plus aujourd'hui. Avant 1988, la Food and Drug Administration, organisme américain, ne disposait pas de processus officiel d'examen préalable à la mise en marché. On a produit trois générations de prothèses de silicone et apporté un certain nombre de changements de moindre importance. La première génération (de 1963 à 1972) était faite d'un gel épais et d'une enveloppe épaisse. La plupart des prothèses ont résisté à l'épreuve du temps. La deuxième génération, elle, (de 1973 au milieu des années 80) avait un gel clair et une enveloppe mince. Les prothèses avaient tendance à se rompre avec les années. Enfin, la troisième génération (du milieu des années 80 à 1992) était revenue au gel épais et à l'enveloppe épaisse. À l'exception de celles fabriquées par Surgitek, ces dernières prothèses se sont montrées résistantes. La concurrence dans le milieu était très forte et les entreprises, pour se distinguer, ont apporté une foule de modifications à leurs produits, comme du gel plus clair, donc plus souple, des enveloppes munies d'une membrane résistante aux fuites, des enveloppes plus ou moins épaisses, des surfaces de différente texture, des enveloppes de taille et de forme différentes, des implants à une ou plusieurs lumières, et ce, toujours dans l'espoir d'arriver à une plus belle apparence. Finalement, plus de 240 genres et 8300 mod- èles de prothèses mammaires de silicone ont été fabriqués aux États-Unis seulement. Par ailleurs, des prothèses gonflables (Simaplast) ont vu le jour à Toulon, en France, en 1965. On compte trois grands modes de fabrication : à joint, à vulcanisation à température élevée et à vulcanisation à température ambiante. En 1973, on a enregistré des taux de dégonflement spontané variant entre 76 et $88 \%$ sur trois ans, et ce, pour de nombreux types de prothèses gonflables. Aussi la plupart des chirurgiens plasticiens ont-ils abandonné leur utilisation. À partir de 1963 jusqu'au moratoire imposé sur les prothèses de gel (6 janvier 1992), à peu près $95 \%$ de toutes les prothèses mises en place étaient remplies de gel de silicone; les autres, soit $5 \%$ seulement, contenaient du sérum physiologique. Depuis le moratoire, les proportions ont été complètement inversées, c'est-à-dire que 95 $\%$ des prothèses contiennent du sérum physiologique et $5 \%$ seulement, du gel. Les prothèses de silicone enduites de polyuréthanne (PU) ont fait leur entrée sur le marché en 1968. Elles ont montré, au cours des 20 années qui ont suivi, leur capacité à réduire la prévalence de la rétraction capsulaire en ramenant les taux à 2 ou $3 \%$ environ. D'autres formes de texture de surface (Biocell, Siltex, implants à structures multiples) ont semblé également réduire la rétraction capsulaire des prothèses de gel mais pas autant, et de beaucoup, que le PU. Les prothèses de forme anatomique remplies de gel semblent mieux convenir à certaines femmes, mais tel n'est pas le cas des prothèses remplies de sérum physiologique ayant une forme ou une texture particulières. Les prothèse de gel ont donné lieu au plus important recours collectif dans l'histoire de la médecine; en effet, des montants totalisant 4,2 milliards de dollars américains ont été adjugés à des femmes porteuses d'implants de silicone. Au cours de la dernière décennie, il s'est fait beaucoup de recherche sur la réaction de l'organisme féminin aux prothèses de gel et une foule d'études ont montré que les prothèses de silicone n'étaient pas associées à l'apparition de quelconque maladie. Aussi l'utilisation des prothèses remplies de gel de silicone a-t-elle été approuvée par Santé Canada dans le cadre d'un programme spécial d'accès. Il est donc maintenant possible de poser ces dernières prothèses chez certaines patientes, c'est-à-dire celles chez qui on croit que le gel donnerait de meilleurs résultats que le sérum physiologique. Toutefois faut-il préciser qu'il ne s'agit pas là d'une autorisation d'utilisation générale illimitée. L'évolution des prothèses mammaires a rempli l'histoire de la deuxième moitié du $\mathrm{XX}^{\mathrm{e}}$ siècle; ses grandeurs et misères ont donné lieu à d'énormes progrès mais aussi à d'amères déceptions. Le monde des prothèses mammaires est vaste et il existe de grandes différences entre les modèles. Le présent article fait l'historique des prothèses mammaires au cours des 50 dernières années.

recalled by Clay-Adams. The manufacturing process was then changed so that the sponges were supplied with higher formaldehyde levels. Pangman subsequently formed the Poly-Plastic Company (USA) to manufacture his own brand of Ivalon implants. They were distributed by the Beverly Hills Surgical Supply Company in Beverly Hills, California (Figure 1). The implant shown in Figure 1, right, has been stored in this original presentation case for the past 47 years (many of the breast implants shown in the present paper are from the author's personal museum of breast implants).

In 1955, Pangman and Wallace (2) reported on the results of their first 400 Ivalon breast prostheses that had been implanted into women. Initially, they used Ivalon sponges that were hand carved to the required shape. Because the outer surfaces of Ivalon prostheses became infiltrated with vascularized tissue, Pangman referred to the 

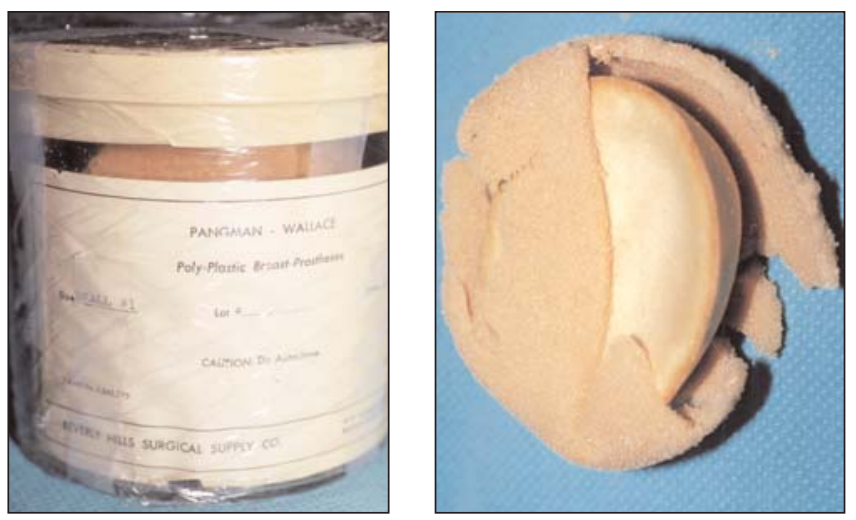

Figure 1) Left Original presentation case; Right Pangman Ivalon double-layered implant (circa 1955) manufactured by the Poly-Plastic Company and distributed by Beverley Hills Surgical Supply Company. This implant has been sitting in this case for 47 years

implant as a "living sponge". Although the initial results with Ivalon were encouraging, after six to 12 months they underwent "shrinkage and compression" and became "very hard". This was likely due to capsular contracture, a process that was not well understood at that time. It produced "shrinkage" because it resulted in the collapse of the sponge material. To address this problem, Pangman introduced several modifications (2). Initially, he developed the Compound Ivalon Polyethylene prosthesis. The inner core of the sponge was removed, wrapped in a polyethylene sac that looked like a layer of cellophane and then reinserted inside the outer shell. It was hoped that this would allow tissue growth into the outer shell, with the polyethylene acting like an inner tube to prevent the collapse of the inner part of the prosthesis. Unfortunately, this did not prevent collapse or firmness. Subsequently, Pangman placed a polyethylene sac around the entire Ivalon implant to reduce tissue ingrowth. This, too, was unsuccessful (3).

In 1955, Pangman developed his double-layered Ivalon sponge implant (Figures 1, right and Figure 2, top right). The outer layer had small pores to encourage tissue ingrowth. The inner layer had very large pores, which he hoped would collapse to decrease firmness when capsular contracture developed. Unfortunately, these implants also developed major firmness within a year of implantation. Wrapping these particular implants in a polyethylene bag did not prevent firmness (4). Initially, it was thought that the firmness was due to calcification of the implant, because such mineralization had been demonstrated in canine studies (5). However, subsequent analyses of Ivalon sponges explanted from patients failed to find calcification (6).

Figure 2, top left, shows a 46-year-old woman who presented to the author in 1979 with class IV contractures, 19 years after she had received Pangman double-layered Ivalon implants. Her appearance was rather classical, almost a trademark for patients who received these early implants. The breasts had become very firm due to excessive capsular contracture. When these implants were removed (Figure 2,
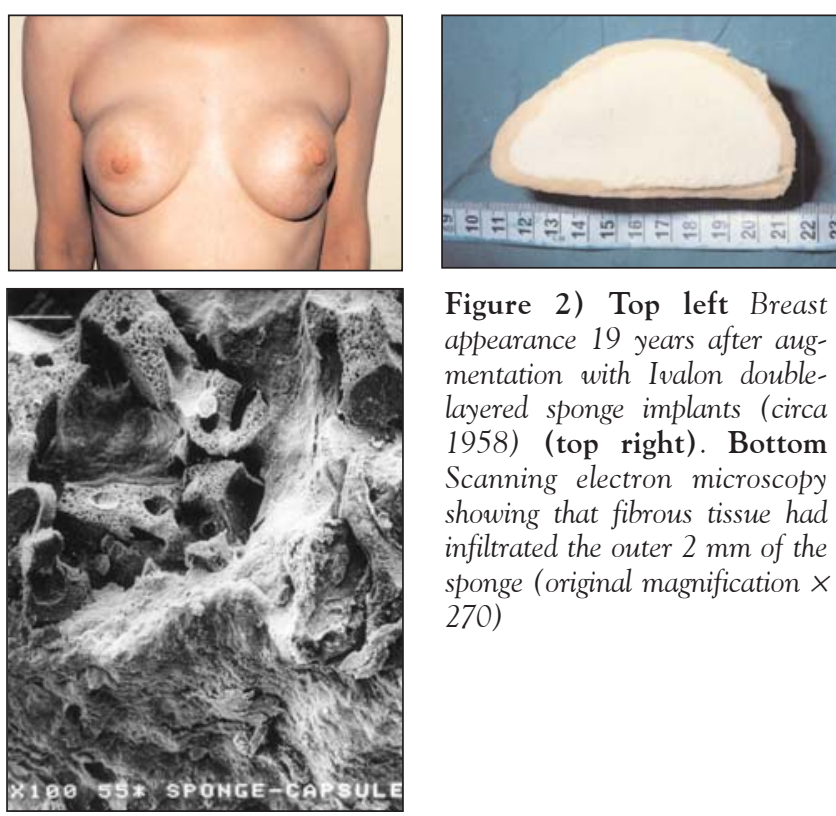

Figure 2) Top left Breast appearance 19 years after augmentation with Ivalon doublelayered sponge implants (circa 1958) (top right). Bottom Scanning electron microscopy showing that fibrous tissue had infiltrated the outer $2 \mathrm{~mm}$ of the sponge (original magnification $x$ 270)

top right), they were surrounded by a thick ( 4 to $5 \mathrm{~mm}$ ) capsule (6). This fibrous capsule had infiltrated the outer $2 \mathrm{~mm}$ of the surface of the sponge (Figure 2, bottom). Once the capsule was cut through, the resulting compression properties of the implants were similar to virginal Ivalon sponge. The firmness of the woman's breasts was due to contracture of the fibrous capsules and not to any change in the implants themselves.

Other manufacturers developed additional brands of Ivalon sponges. These included the Rubatex, Ivano and Prosthex Ivalon sponges (7) (USA). These were implanted by a number of surgeons during the 1950s (7-10). In 1961, a survey performed by Harris (11) estimated that approximately 16,600 Ivalon implants (some with polyethylene covering) had been inserted by 184 of the 294 existing plastic surgeons in practice at that time. In all cases, patients with Ivalon implants developed significant capsular contracture with very firm breasts and a loss of about $25 \%$ of their breast volume. In 1962, Dukes and Mitchley (12) reported that rats had developed sarcomatous tumours after Ivalon sponges were implanted. After silicone gel implants were introduced in 1963, Ivalon was no longer used for breast augmentation.

\section{Other sponges}

From 1952 to 1962, other sponges were also used for breast augmentation. In 1952, Naso (13) reported on the use of a polyethylene sponge. Other surgeons used Etheron (USA), a form of polyether sponge (14-17). Paule Regneault (17), who practised in Montreal, reported on the insertion of 174 Etheron sponge prostheses for breast augmentation. In addition to developing major capsular contracture, these implants were also associated with infection and erosion. Another implant that was used at this time was the Polystan (Ferrosan Company, USA) sponge (7). This was 

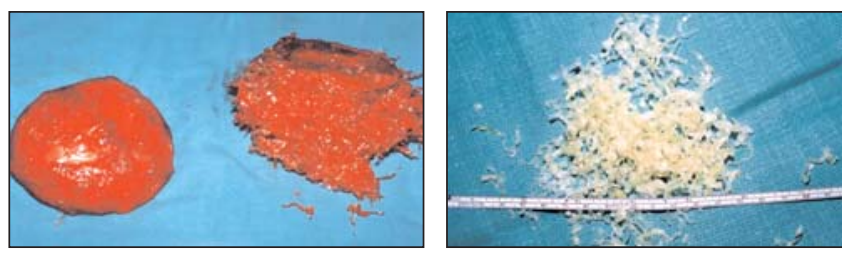

Figure 3) Left Implants inserted in 1963 in Turkey; Right the casing contained numerous shredded strips of polyethylene, each about $2 \mathrm{~mm}$ wide

composed of fabric tapes that were cut by machine and then wound by hand into a ball. In 1963, Edwards (18) introduced an implant with an inner sponge of Silastic (Mentor Corporation, USA) surrounded by a thin layer of Teflon (Roger Klein Co, USA). The Teflon shell, like a form of felt covering, was designed to prevent fibrous ingrowth to restrict postoperative shrinking from capsular contracture. However, breasts in which these sponges were implanted also became very firm and lost significant volume after six to 12 months. Another type of implant that was used from 1958 to 1962 consisted of shredded polyethylene strips enclosed in a casing (19). Figure 3 shows two such implants that we removed from a patient in 1984. These had been inserted in Turkey in 1963 as a 17th birthday present from the recipient's parents! Once the casing was cut through and washed with saline there were numerous shredded strips of polyethylene, which were about $2 \mathrm{~mm}$ in width.

All of the implants from that era had a similar outcome. Within a year of implantation, they tended to develop major capsular contracture, breast firmness and a loss of breast volume. Because of this high complication rate, the popularity of breast augmentation surgery declined progressively until 1963, when the silicone gel implant was introduced (20).

\section{3: SILICONE GEL BREAST IMPLANTS}

Cronin and Gerow (20) introduced the silicone gel breast implant in 1963 as a new "natural feel" implant. Since then, many types and models of implants have been developed. There is no such thing as a 'standard' silicone gel breast implant. Implants have consisted of a rubber-like silicone elastomer envelope (shell) that varied in thickness from 0.075 to $0.75 \mathrm{~mm}$ and enclosed a known volume of silicone gel (21) ranging from 80 to $800 \mathrm{~cm}^{3}$. The elastomer is composed of extensively cross-linked high molecular weight components, together with $16.4 \%$ to $26.9 \%$ amorphous fumed silica filler, which is used as a reinforcing agent. The gel consists of a mixture of low molecular weight (6000 to $38,000 \mathrm{Da}$ ) silicone fluid and high molecular weight (up to 404,000 Da) components. The chemical composition and average molecular weight of the gel differed from manufacturer to manufacturer and from time to time. Solvent extraction of the envelope and the gel has revealed 30 different linear and cyclic components (21).

\section{Implant vintage}

First-generation implants: There have been three main generations of silicone gel breast implants (Figure 4, top
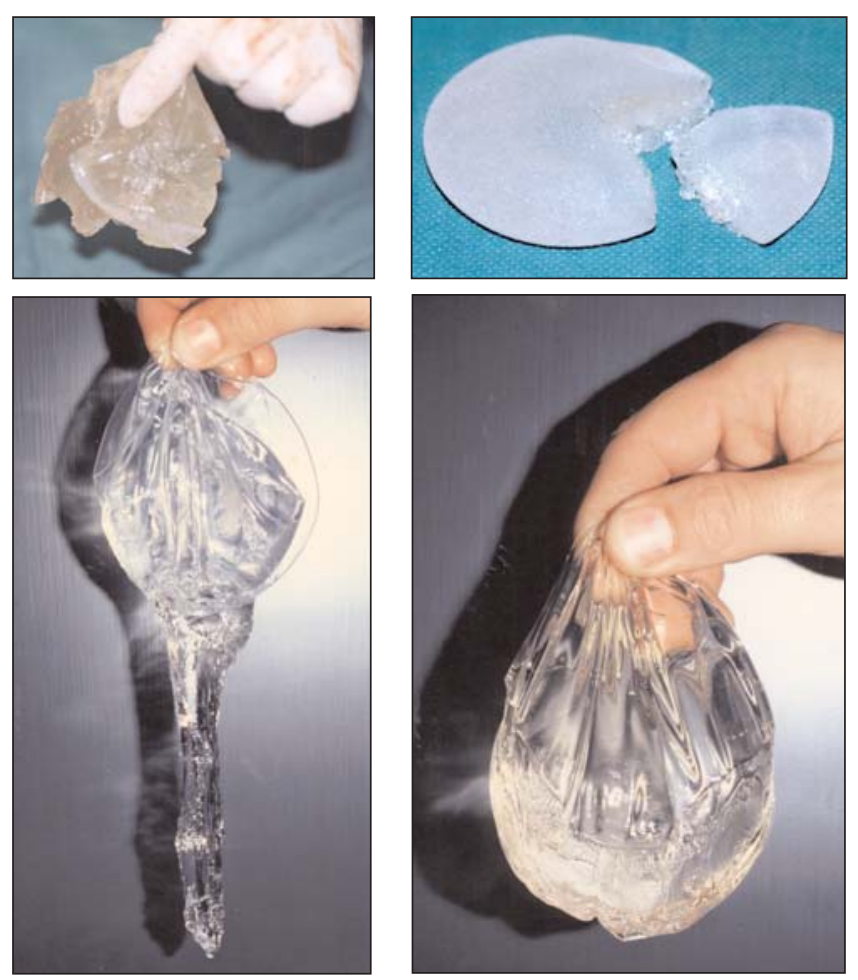

Figure 4) Silicone gel implant vintage. Top left First generation (1966) (thick wall, thick gel); Bottom left Second generation (1977) (thin wall, thin gel); Bottom right Third generation (1989) (thick wall, thick gel); and Top right Contemporary cohesive gel implant

left) and a number of lesser variations (22-28). First-generation implants were made from approximately 1963 to 1972. During that time, Dow Corning had an almost exclusive monopoly on their manufacture. The implants were composed of a thick (firm) gel and a thick and firm elastomeric wall (Figure 4, top left). From 1963 to 1968, the shells were $0.75 \mathrm{~mm}$ thick. They were prepared by using a molding technique to produce a seamed shell, which was subsequently filled with gel. From 1969 onward, a different technology was used and all shells were seamless (the Silastic 0 implant (Dow Corning, USA). Automated dipcoating of a mandrel into a dispersion fluid produced these shells. The shell was then removed, gel was injected into it, and the injection site was sealed with adhesive silicone. First-generation implants had woven Dacron (Dupont Co, USA) patches on their posterior surfaces to anchor them to the chest wall in an attempt to restrict ptosis. Implants made in 1963 had a single patch that covered the entire posterior wall (the "Cronin seamed prosthesis"). In 1964, four-quadrant patches were used. In 1968, this configuration was changed to three, four or five patches, depending on the implant volume. One of those patches was usually shaped like a dumbbell. First-generation implants have proved to be much stronger than those developed subsequently $(22,23)$. This is likely due to the thickness of their elastomer shells. Most women with first-generation implants developed very firm breasts within a year of their surgery. This was likely due to capsular contracture. 
However, it was surmised that this firmness was due, at least in part, to the firmness of the implants. Softer (second-generation) implants were therefore developed with the idea that they would result in softer breasts.

Second-generation implants: Second-generation implants were introduced in the United States from 1972 to 1975. They were used until the mid-1980s. They had a thin, watery, 'responsive' gel that was less viscous than first-generation implants (Figure 4, bottom left), and a thin ( 0.13 $\mathrm{mm})$ and softer wall. The thickness or firmness of the gel was related to the relative amount of highly cross-linked material in the gel. The thick or firm gel contained about $50 \%$ highly cross-linked silicone and about 50\% low molecular weight chains. By contrast, the thin gel contained only about $20 \%$ highly cross-linked silicone and $80 \%$ low molecular weight chains.

By that time, several other manufacturers had entered the silicone gel breast implant market. Heyer-Schulte (USA) entered in 1972 in the United States and in 1974 in Canada. Early models of their implants had fenestrated fixation patches rather than Dacron patches. Those patches had holes $1 \mathrm{~mm}$ in diameter, into which tissue could grow to provide fixation. Medical Engineering Corporation (MEC), which later became Surgitek (USA), began to market gel implants in the United States in 1972 and in Canada in 1979. These were called Perras-Papillon implants in honour of the two Montreal plastic surgeons who had contributed to their design. Dow Corning introduced its second-generation gel implants in the United States in 1975 and in Canada in 1978. Surgeons soon noticed that many patients with second-generation implants also developed firm breasts, despite the 'soft' nature of the implants. When those patients underwent revisionary surgery, a number of the implants were found to be disrupted (15-19). This set the stage for the development of the third-generation implant.

Third generation implants: The third-generation implant (27) had a stronger and thicker ( 0.30 to $0.50 \mathrm{~mm}$ ) (high performance) shell and a much more cohesive gel than the second-generation implant (Figure 4, bottom right). Thirdgeneration implants also had a 'barrier layer' to reduce the diffusion of low molecular weight (4000 to $24,000 \mathrm{Da}$ ) silicone oil, which was thought to contribute to capsular contracture. The introduction of third-generation implants was geographically dependent (26). McGhan (Intrashiel) (USA) third-generation implants were introduced in the United States in 1979 and in Canada in 1980. The corresponding Dow Corning (Silastic II) implants were introduced in the United States in 1981 and in Canada in 1984. Surgitek strong, cohesive, low-bleed (SCL) implants were introduced in the United States in 1986 and in Canada in 1988. Both Surgitek and McGhan implants had a diphenyl barrier layer incorporated within the shell. Dow Corning (Silastic II) implants had a $0.010 \mathrm{~mm}$ barrier coat of fluorosilicone on the interior surface of the shell. The product information sheets with these implants stated that they had a "bleed of $20.8 \mathrm{mg}$ at 12 months". The actual thickness of the shells of third-generation implants (like second-generation implants) was quite variable. The manufacturer listed the shell thickness of Intrashiel shells to be $0.35 \mathrm{~mm}$. However, subsequent analysis showed a range of shell thickness from 0.13 to $0.35 \mathrm{~mm}$ (28). When textured gel implants were introduced between 1987 and 1989, their shells were thicker $(0.50 \mathrm{~mm})$ than earlier third-generation shells $(0.30$ to $0.35 \mathrm{~mm})$.

Recent studies have indicated that, with the exception of Surgitek implants, third-generation implants have proved to be much more durable than second-generation implants $(26,27)$. However, the effectiveness of the barrier layer to restrict silicone bleed remains unproved. In addition, there is no proof of any relationship between tissue silicone levels and capsular contracture. No study of adequate power has held all other variables constant and compared actual tissue silicone measurements with capsular contracture (28).

\section{Double-lumen implants}

Standard double-lumen implants have two shells. The inner lumen is gel filled and the outer is saline filled. The outer lumen was supposed to form, in theory at least, an additional layer against silicone oil diffusion or gel leakage. However, this feature proved to be ineffective. In fact, no data can be found to support such a function (28-30). In the late 1980 s, double-lumen implants, mostly made by McGhan Corporation, constituted about $15 \%$ of all implants that were used. Dow Corning also made doublelumen implants, but only on special order.

\section{Implant identification}

In women being studied, it is often difficult to know what implants might be in place and what their characteristics might be. In North America, gel implants have been made by more than 10 companies. Many changed their names and ownership over the years. Most of the companies no longer exist. Companies often introduced designs conceived by individual surgeons, usually without testing. No formal process of premarket testing was in effect until 1988. The implant business was competitive, and companies introduced changes such as softer gels; barrier low-bleed shells; greater or lesser shell thickness; surface texturing; various sizes, contours and shapes; and multiple lumens in search for better aesthetics. These changes were introduced at different times and usually affected some, but not all, of the company's products. It has not been possible to locate much in the way of clinical pretesting of these changes, some of which had unintended consequences.

The composition of gels changed over time and differed among the various manufacturers that entered and left the market periodically. The chemical composition and resulting properties of the elastomeric shells also differed between manufacturers, depending on the implant company and its source of dispersion fluids (to dip-coat the gel). Dow Corning always made its own gels and elastomers. Other manufacturers obtained their gels and dispersion fluids from a variety of sources, at varying times, including Dow 
Corning, General Electric, Admiral Materials, Applied Silicone, Polymer Technologies, Nusil (which later became a subsidiary of Union Carbide) and International Silicone Corporation (USA). Different manufacturers between 1978 and 1986 marketed various "high performance" shells. It is not clear what actual chemical changes were made to make these shells high performance.

The chronology of McGhan implants indicates the complexity of implant development over the years. McGhan Medical Corporation began marketing gel-filled breast implants in 1974. The company was merged with Minnesota Mining and Manufacturing (3M) Company (USA) in 1980. McGhan acquired the company back from 3M in 1984. First American (USA) acquired it in 1985. The name was later changed to Inamed (USA). In 1975, the product line included smooth, single-lumen saline implants, single-lumen gel implants, combination gel-saline implants and the first double-lumen implants. A triplelumen model (with saline in the outer lumen and two gel lumens) was added in 1979. Except for the single-lumen gel implants, all of these products were modified and 'updated' by 1981 . The changes that were involved in the updating process were not generally elucidated. Reverse doublelumen implants were added in 1987, including a double-gel model (with gel in both lumens) in 1991. In addition, new shells were introduced periodically. A 'silica free' (the exact meaning of this term is not clear) low-bleed outer layer (Natrashiel) (USA) appeared in 1977. A similar low-bleed shell (Natrashiel II) and a double-layer, increased-strength, decreased-bleed (Ultra High Performance [UHP]) shell were introduced in 1978. A low-bleed model containing two high-performance elastomer layers with a barrier layer was introduced in 1979 (Intrashiel). These implants had a variable thickness ranging from 0.13 to $0.35 \mathrm{~mm}$.

In 1985, Mentor (USA) introduced a reverse doublelumen implant with gel on the outside and saline inside (the Becker implant). In 1987, a Siltex (Mentor Corp, USA) textured coating was applied. This model remains popular today. In 1992, after the moratorium, new models of gel and saline implants were introduced. Many of the changes in these implants have remained proprietary.

Over the years, there have been more than 240 styles and 8300 models of silicone gel breast implants manufactured in the United States alone (28,31-33). Of particular interest today, two types of gel implants were intentionally manufactured without a shell: the Cavon implant (Cox Uphoff International, USA) and one style of the Aesthetech (USA) implant. Both implants were used in several areas of the United States from 1979 to 1986.

\section{Prevalence}

The implantation of silicone gel breast implants began from a small base and increased slowly. From 1962 to 1970, only about 50,000 women received gel implants in the United States (28). Subsequently, the number of women rose annually. In 1982, about 100,000 women received breast implants. From 1983 to 1991, this number remained con- stant at 120,000 to 130,000 per year. During that time period, breast augmentation became the most common aesthetic surgical procedure performed in North America. Current estimates indicate that by 1992, about two million women had received breast implants and that over $95 \%$ of those implants were gel filled. During 2001, approximately 217,000 women received breast implants (The American Society for Aesthetic Plastic Surgery National Data Bank, 2001 Statistics). Ninety-five per cent of these were salinefilled implants. Only 5\% were gel filled. It is interesting to note that the prevalence of breast implants among women over 18 years of age is only about $1 \%$ (34).

\section{Moratorium}

On January 6, 1992, Dr David Kessler, the then commissioner of the United States Food and Drug Administration (FDA) announced a moratorium on the use of silicone gelfilled breast implants (35). This moratorium was also adopted in Canada. From that time until 1994, only a few women in Canada received silicone gel breast implants (personal communication, B Pieterson, Director, Therapeutic Products Directorate, Health Canada). They were mastectomy patients with exceptional circumstances, who received approval on compassionate grounds, because the quality of their final result would be more compromised with saline implants (with ripples and folds on the breast surface) than with gel implants. From 1995 through 1988, because of the heightened controversy about gel implants, none were approved for use in Canada. In 1999, after many scientific studies indicated that there was no association between gel implants and medical disease, silicone gel breast implants again became available, but only under the Special Access Program. This program has continued to the present time. It provides approval for the use of silicone gel implants for the following patients: mastectomy, augmentation after failed saline implants (usually with ripples and folds) and primary augmentation if a saline failure is strongly predicted. Health Canada has not approved the use of gel implants for general use. From 1999 until January 2002, there were only 1366 applications to Health Canada for silicone gel breast implants.

In the United States, since the moratorium, gel implants have been available only for patients who are enrolled in the Special Adjunct Study, with an FDA-approved protocol. Patients in that study were only those with mastectomy or severe developmental deformity, or those with a failed augmentation following saline implants. The objectives of the adjunct study are to carefully analyze infection, seroma, capsular contracture, rupture and the incidence of rheumatic diseases over a five-year period. The results of those studies are being evaluated.

\section{Cohesive gel implants}

The major disadvantage of saline-filled implants is the development of ripples and folds on the surface of the augmented breast, particularly when the implants are placed in the subglandular position when there is a paucity (less than 

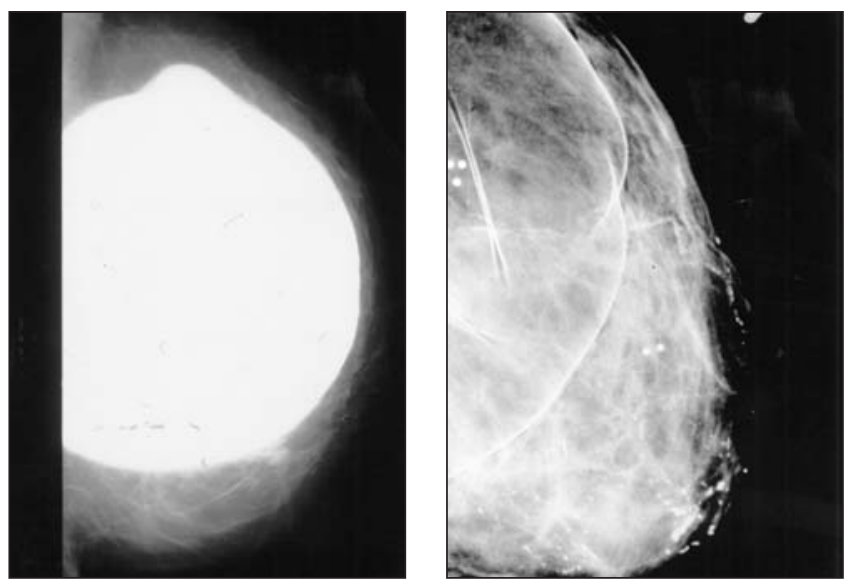

Figure 5) Left Silicone gel and saline-filled breast implants are radiopaque on film screen mammography. Right By contrast, Trilucent (Lipomatrix) soybean oil-filled implants are radiolucent

$2 \mathrm{~cm}$ ) of overlying breast tissue. This problem results because saline solution is much less viscous than silicone gel. The viscosity of the gel tends to cushion and eliminate these folds. By contrast, the watery nature of the saline promotes surface irregularities. To overcome this problem, Mentor and McGhan have developed cohesive gel implants (36). These implants have a very viscous cohesive gel (Figure 4, top right) that was designed to restrict the development of ripples and folds, and to prevent the migration of the gel if the implant should rupture. Although these implants have been used extensively in Europe and Sweden, only a small number (fewer than 1000) have been implanted in Canada.

The largest series of cohesive gel implants came from Akademikliniken in Stockholdm, Sweden, where a group of seven plastic surgeons implanted $1676 \mathrm{McGhan}$ style 410 anatomic cohesive gel implants in 823 women (36). These implants, which were developed by Dr John Tebbetts in Dallas, Texas, are available with different base widths and in nine models, with different relationships between projection and height referred to by McGhan as the Biodimensional system. The implants are named first depending on their height - full, moderate or low (F, M or $\mathrm{L})$, and second on their ventral projection - full, moderate or low (F, M or L). Thus, an implant with a full height and a moderate projection is named 'FM model'.

Cohesive gel implants are somewhat firmer than traditional gel implants. Anatomical cohesive models tend to have a stable form, in that if the implant is turned in different directions, its anatomical shape remains. This property is not shared by traditional gel implants. In addition, cohesive gel implants appear to have a low prevalence of capsular contracture (less than $5 \%$ in the $75 \%$ of 1676 breasts evaluated in the Stockholm study).

\section{Trilucent implants}

One of the most important disadvantages of silicone gelfilled and saline-filled breast implants is that they are
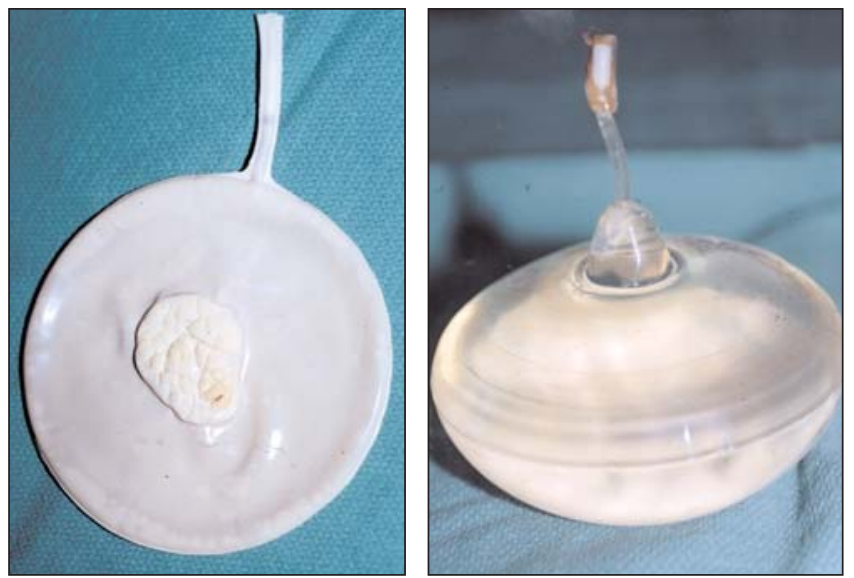

Figure 6) Simaplast breast implants were the first inflatable breast implants. Left The initial model (1965) had a cream-coloured, seamed shell, with a filling tube and Teflon plug attached to one side. Right The second model (1968) had a clear shell with a filling tube and Teflon plug

radiopaque on film screen mammography, obscuring varying amounts of breast parenchyma (Figure 5, left). The primary element of breast parenchyma is carbon, which has an effective atomic number $(Z)$ of 6 (37). Both silicone $(Z=10.37)$ and saline $(Z=7.56)$ are radiopaque because they have effective atomic numbers higher than breast parenchyma. By contrast, implants filled with triglycerides such as soybean oil (Trilucent, LipoMatrix, USA) are radiolucent (Figure 5, right) because they have an effective atomic number (5.88) near that of carbon. This advantage, together with the silicone gel implant controversy following the moratorium in 1992, stimulated clinical trials of Trilucent soybean oil-filled implants, mainly in the United Kingdom (38).

Between 1995 and 1999, more than 18,000 women in the United Kingdom received Trilucent implants. Although the soybean oil in those implants was initially thought to be innocuous if the implants were to rupture, by 1999, several hundred patients had presented with acute unilateral breast enlargement following rupture (39). Potentially toxic aldehydes were detected in some cases. In addition, the transponder on the implant was shown to interfere with magnetic resonance imaging studies. These findings stimulated the Medical Devices Agency (MDA) of the United Kingdom to release an emergency recall of all implanted Trilucent implants. The MDA ran an extensive advertising campaign promoting the urgent removal of these implants. The MDA also suggested that women with these implants should not attempt breastfeeding unless the implants were removed. The MDA offered to cover the cost of all surgery for these patients. It is particularly interesting that, in spite of all of these developments, fewer than $5 \%$ of the 18,000 women with Trilucent implants chose to have their implants removed.

\section{INFLATABLE IMPLANTS}

\section{Implant vintage}

Cronin originally considered the use of saline as the filler 

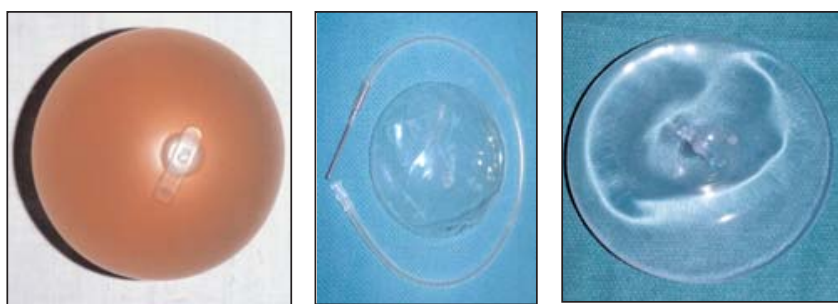

Figure 7) Inflatable saline-filled breast implants. Left Jenny (HeyerSchulte) (1969) with a room temperature vulcanized opaque shell; Centre Varifil (Dow Corning) (1977) with a leaflet filling valve and a High-Performance shell; Right Mentor implant (2001) with a diaphragm valve and a High-Performance shell

for implants in the early 1960s. However, this idea was discarded because 'gel implants remain normally expanded even when torn'. Cronin had anticipated that "it seemed unlikely that leakage could be avoided for life". Like silicone gel-filled breast implants, there have been at least three 'eras' and a number of lesser variations of inflatable implant shell manufacture $(8,32)$. There was considerable overlap between these eras, depending on the manufacturer and model of the implant. The first era was characterized by the Simaplast (Simaplast Co, France) implant. Shells were $0.35 \mathrm{~mm}$ thick and were seamed. Failure of these implants was frequent and occurred at the seams and valves (which were often Teflon plugs pushed into a hollow injection tube and sometimes tied with a suture) (Figure 6).

After 1968, all shells made in the United States were seamless. They were formed by dipping a mandrel into a dispersion fluid. Second-era saline implants (1968 to 1976) were made using a high-temperature vulcanized (HTV) platinum catalyzed process. They had a thinner shell than first-era implants and a correspondingly high failure rate. Third-era saline implants (1968 to 1992) were made using a room temperature vulcanized (RTV) tin catalyzed procedure. These shells appear to be stronger and more durable than the HTV shells $(40,41)$. However, not enough time has elapsed to predict this with confidence (28). The third era may have given way to a fourth era, with changes resulting from the FDA moratorium. These changes have remained proprietary.

\section{Simaplast implants}

Inflatable breast implants were introduced in 1965 by $\mathrm{Dr}$ Henri G Arion (the Simaplast implant) (41) in Toulon, France (the birthplace of Brigitte Bardot). Dr Arion was a physics engineer before becoming a plastic surgeon. He developed his implant in the early 1960s, patented it in 1964 and began using it clinically in 1965 (personal communication, HG Arion, Toulons, France). The initial Simaplast prosthesis (42) consisted of a cream-coloured elastomeric shell with a peripheral circumferential seam, with a filling tube and valve attached permanently to one side (Figure 6, left). The seam extended along the full length of the filler tube. After filling, a Teflon plug was inserted into the filling tube to provide a watertight seal. This initial model was introduced in North America in
1969. The implant shown in Figure 6, left (courtesy of Dr Jean-Luc Bergeron, Sherbrooke, Quebec) was removed from a woman in 1999, 29 years after it was inserted. This implant had remained clinically intact for 29 years. The contralateral implant had deflated many years earlier.

In 1968, a second model of Simaplast inflatable implant was introduced in France $(42,43)$. It was not introduced in North America until 1975. It had a clear, seamed, elastomeric shell with a seamless filling tube attached to the posterior surface of the implant (Figure 7, centre). The shell thickness was $0.35 \mathrm{~mm}$. After filling, a Teflon plug was inserted into the end of the filling tube, which was then buried into a pocket on the posterior surface of the prosthesis to conceal it. Initially, Arion suggested that the filling solution for these implants should be a hypertonic solution, consisting of $6 \%$ dextran in normal saline. However, many surgeons used $6 \%$ dextran or saline alone as the filling solution $(43,44)$. Subsequently, Arion recommended using saline alone.

The second model of Simaplast prostheses came in two sizes (42): SM 16/10 (100 to $250 \mathrm{~cm}^{3}$ ) and SM 16/11 (200 to $350 \mathrm{~cm}^{3}$ ). These implants were inserted in the subglandular plane through a smaller incision than gel implants. They could be inflated to varying sizes, allowing a wider range of final breast sizes. These implants were marketed initially by the Simaplast Company in Toulon, France. In 1966, Roger Klein set up an American division of the company (Simaplast, Inc) in Yonkers, New York, with a branch in Watertown, Massachusetts $(44,45)$. Chas F Thackray, Ltd also marketed the prosthesis in the United Kingdom, and Real Laperierre Inc (Montreal, Canada) marketed it in Canada. It is interesting that the product information brochure for this implant recommended that if a patient became pregnant, then the prosthesis should be "partially emptied at the second month of the pregnancy to minimize the cutaneous distention of the gravid state". The prosthesis could then be refilled after weaning.

In 1965, Arion presented the results of his first 15 patients (41). He stated that the Simaplast implant was the first one to produce a truly soft "bouncy" breast. By 1967, about 500 patients had received these implants (39). In 1967, the Simaplast Company was sold to the pharmaceutical firm Perdue Frederick (France) (45). The implant division of this company was later changed to Medical Application Plastic. There is only a small number of published reports in the world literature describing the Simaplast implant (41-47). In 1969, Tabari (43) described 30 cases of bilateral breast augmentation, with $10 \%$ of those implants undergoing early spontaneous deflation. By 1972, Williams (44) reported a spontaneous deflation incidence for Simaplast implants of $76 \%$ within three years of implantation. Simaplast implants were then removed from the market. Only approximately 6000 pairs of Simaplast implants were sold worldwide (personal communication, HG Arion). In 1999, Peters and colleagues (47) described two Simaplast implants that were removed after 23 years in situ. They were both clinically intact. The anterior surface 
of both implants had developed large areas of calcification (Figure 7, centre), which appeared to develop after an abrasion to the surface of the elastomeric shell (48). One of the implants had undergone significant autoinflation.

\section{Heyer-Schulte inflatable implants}

The first inflatable implants manufactured in the United States were made by Heyer-Schulte $(28,49,50)$ in 1968. They were designed by Dr Henry Jenny and were called the Jenny implant (Figure 7, left). They were round and their elastomeric shell was opaque and was $0.40 \mathrm{~mm}$ thick. They were the first RTV implants manufactured by HeyerSchulte. Jenny first implanted them in December 1968. Subsequently, in 1971, clear and round HTV implants (style 1000) were introduced. In 1972, the teardrop-shaped HTV implant, which was designed by Dr Lawrence Birnbaum (style 1100), became available. In 1973, a second teardrop-shaped HTV implant, which was designed by Dr Dirian M Seropian, was introduced (style 1300). Other models of round and teardrop implants followed. An optional Dacron backing could be ordered on many of these inflatable implants. Others came with a fenestrated patch, into which tissue could grow to anchor the implant. In 1974, Heyer-Schulte was acquired by American Hospital Supply and the name was changed to American Hospital Supply Corporation. Mentor subsequently acquired this company in 1984. Mentor continued to manufacture the inflatable silicone gel and double lumen models. In 1992, new models of these implants were introduced. Many of the specifications of these models are not known.

Dow Corning produced its first inflatable breast implant in 1970 (51). This implant was designed and tested by Dr Paule Regnault in Montreal. Unfortunately, it had a deflation rate of $8 \%$ during the first year, forcing the project to discontinue. Dow Corning re-entered this area in 1977 with the development of the Varifil implant (Figure 7, centre). This was the first implant of any type with the stronger 'High Performance' elastomeric shell. However, these implants also had a high leakage rate, which was probably related to their leaflet valve. This leakage problem forced Dow Corning to discontinue this implant in 1982.

By 1973, several types of saline implants had demonstrated spontaneous deflation rates of $76 \%$ to $88 \%$ over three years $(40,45,47,50)$. Leaks were noted in seams, valve stems and valve mechanisms. Many of these implants were therefore removed from the market. Most surgeons became discouraged with this high failure rate and began to use only silicone gel-filled implants. Heyer-Schulte subsequently became the dominant player in the inflatable implant market. It introduced the hydrocephalic valve (developed by $\mathrm{Mr}$ Schulte), which decreased the deflation rate significantly. Over the years, Heyer-Schulte developed several unique models of implants (49). For example, the Hartley doublelumen implant was designed so that the outer saline lumen could be punctured and deflated to reduce the firmness resulting from capsular contracture. From 1975 to 1983, this implant was available in six styles. However, it was sub-
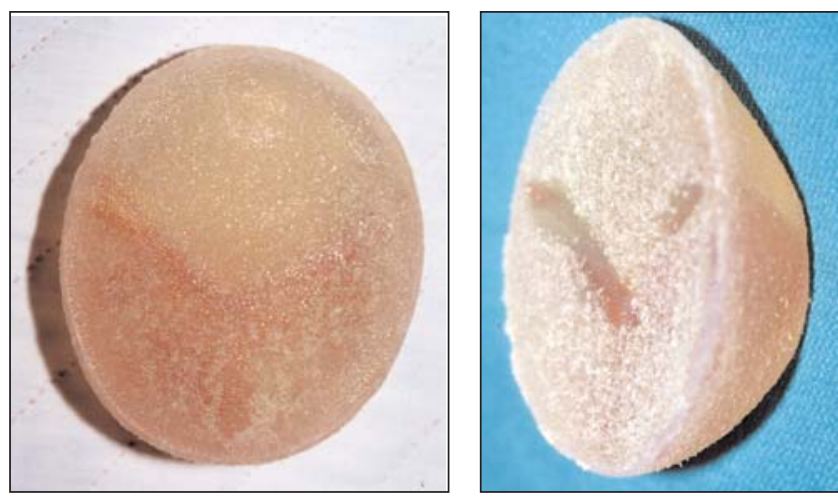

Figure 8) The Ashley Natural Y Implant (1969): A silicone gel-filled implant with a $2 \mathrm{~mm}$ layer of polyurethane (PU) on the surface. The inverted Y-shaped baffle or internal divider controlled the shape of the implant, by preventing the gel from sagging to its central part. The posterior aspect of this implant is flat

sequently shown that this feature was not effective in preventing capsular contracture (28).

In 1980, Worton and coworkers (52) described a 'new' mechanism to account for the late leakage observed with inflatable implants. This failure did not develop until six to seven years after insertion. In those patients, implants developed a small hole at the end of one of the wrinkles in the elastomeric shell. This was termed the 'fold flaw' leak and was thought to result from an 'internal abrasion' at a wrinkled (and presumably weakened) site in the shell. While this mechanism has not been proved scientifically, it seems logical. This type of leak would be expected to be more common in an implant that was underinflated, which would allow more folds to develop. It would also be expected to be more common in saline implants than in gel implants because the more viscous nature of the gel would 'cushion' folds in the shell. In 1996, Tebbetts (53) provided further support for the fold flaw theory. He showed that in the body, all smooth-shelled round saline implants fall to the bottom of the periprosthetic pocket, so that the upper pole of the implant is always collapsed and wrinkled, even if the implant is overfilled $15 \%$ past the manufacturer's recommended volume.

From 1963 through 1991, about 95\% of all implanted breast prostheses were filled with silicone gel, rather than saline (28). However, since the moratorium on silicone gel breast implants (January 6, 1992), the use of inflatable saline implants has escalated. In the early and mid-1990s, there were some problems with deflation of certain models of saline implants, particularly those with leaflet valves. Subsequently, most saline implants have incorporated diaphragm valves. In Canada, most plastic surgeons have used smooth-walled implants. Textured saline implants became freely available in May 1997. Today, 95\% of all breast implants inserted are saline filled. Only $5 \%$ are gel filled, and those are used only under the Special Access Program of the Therapeutic Products Directorate of Health Canada. 

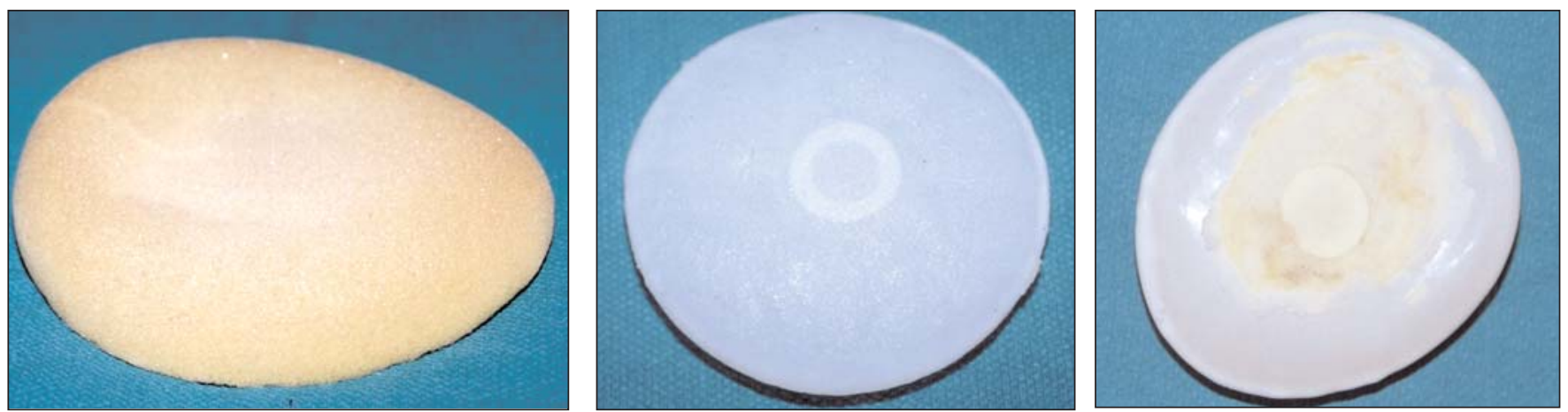

Figure 9) Polyurethane (PU) coated silicone gel-filled implants. Left Heyer-Schulte (1972), in original presentation case for the past 30 years; Centre Replicon PU (1990) with circular white ring on posterior surface; Right Replicon PU (1990) explanted after 11 years. Much of the PU has separated from the implant surface. This shed PU becomes incorporated into the capsule (Figure 10, right)
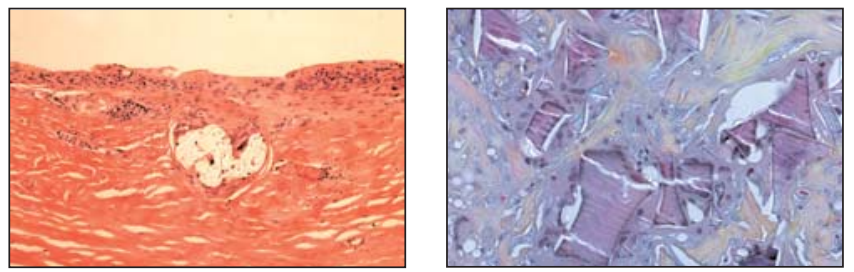

Figure 10) Left Linear orientation of collagen in a contracted silicone gel implant capsule. The inner surface of the capsule shows synovial metaplasia (hematoxylin and eosin stain, original magnification $\times 100$ ). Right Fragments of shed polyurethane (purple) have been incorporated into the capsule and have broken up the linearity of the collagen (green) (World Health Organization stain, original magnification $\times 250$ )

There is little recent information on the leakage properties of modern saline inflatable implants. In 1996, Gibney (54) reported a three-year deflation rate of $0.7 \%$ in 150 Mentor H/S implants with the diaphragm valve design (with plugs). In a recent research study by Gutowski and coworkers (55), which was funded by the American Society of Plastic Surgery, the rate of spontaneous deflation for 995 saline-filled implants inserted between 1980 and 1989 was $4.7 \%$, with a mean follow-up of six years. The rate of deflation of modern saline-filled implants is likely less than $1 \%$ per year. Over the years, the concept of deflation of saline implants has been viewed as an all or nothing phenomenon - once there was a defect in the implant, there was complete or near complete deflation of the involved implant. The concept of partial deflation of a saline implant is relatively new. There have been only a few reports of partial deflation $(56,57)$, which seems to be more common in implants with a leaf valve mechanism.

\section{TEXTURED IMPLANTS}

\section{Polyurethane: The Ashley Natural Y Implant}

The first textured breast implant was developed and patented in 1968 by Drs Franklin Ashley and William John Pangman II. It was known as the Ashley Natural Y Implant (58). It was a high profile, clear-shelled silicone gel-filled implant with a 1.5 to $2.0 \mathrm{~mm}$ layer of PU on the surface $(58,59)$. Figure 8 shows an early example of this type of implant, which was inserted in 1969 and explanted intact in 1999 (Courtesy of Dr Peter Wyshynski, Waterloo, Ontario). These implants had an inverted Y-shaped baffle or internal divider that was designed to control the shape of the implant by preventing the gel from sagging to the deep and central part of the implant (Figure 8). Early models of these implants had a flat posterior surface that helped to control the orientation of the implant (Figure 8). These implants were manufactured by the Poly-Plastic Company (USA), which was originally formed by Dr Pangman to manufacture his Ivalon prostheses. In 1969, Rudy Schulte joined Dr Pangman's company to manufacture Ashley PU implants.

In 1971, Heyer-Schulte acquired the rights for the Ashley Natural Y implants from Poly-Plastics (31) and manufactured about $2000 \mathrm{PU}$ implants over the next few years. One such PU implant is shown in Figure 9, left. This is likely the only existing virginal Heyer-Schulte PU implant from that era. From 1971 to 1973, HeyerSchulte/Poly-Plastics also manufactured two models of saline-filled inflatable implants with internal PU sponges, which were used in an attempt to improve the shape of these implants. In 1974, Heyer-Schulte was acquired by American Hospital Supply, which did not manufacture further PU implants.

Subsequently, many companies manufactured their own versions of PU implants. Most of these implants were manufactured without the Y-septum. Cox-Uphoff International (USA) manufactured PU implants from 1979 until 1981. In 1982, the Aesthetech Corporation (USA) was formed and manufactured the Optimam model from 1982 to 1991 . The Meme was made from 1982 to 1985 . The Meme Moderate Profile (MP) implant replaced it from 1985 to 1991 (28,32). The Replicon PU implant was made from 1984 to 1991. These implants had a small white 'ring' on the posterior surface (Figure 9, centre). The PU foam used in these models had 80 to 100 open pores per linear inch, with a pore size of 200 to $500 \mu \mathrm{m}$ in diameter (28). About $1.35 \mathrm{~g}$ of PU foam covered the average implant. All PU implant brands were acquired by Cooper Laboratories (USA) in 1987 and then by Medical Engineering Corporation 
(Surgitek) in 1988, which continued to manufacture the Meme, Replicon and Optimam implants until domestic sales were suspended in 1991. The elastomer shell thickness was $0.075 \mathrm{~mm}$ for the Meme, $0.23 \mathrm{~mm}$ for the Replicon and 0.23 $\mathrm{mm}$ for the MemeMP. These dimensions probably accounted for the high rupture rates of the Meme implants (25).

PU-coated implants became very popular during the 1980s because their coating appeared to markedly reduce capsular contracture (58-69). PU capsular contracture rates of $1 \%$ to $2 \%$ were common after breast augmentation and 2\% to 3\% after mastectomy reconstruction. From 1987 to 1991, about 19\% of all implants inserted in the United States were PU coated (25). The most likely explanation for their reduced rate of capsular contracture is that tissue grows into the interstices of the PU, prolonging chronic inflammation, disorienting collagen molecules and weakening their contractile forces (69-71). In addition, particles of PU, which are shed from the implant surface, become incorporated into the capsule, further breaking up the linearity of the collagen.

In the human breast, the layer of foam coating on a PU implant has been shown to separate from the elastomeric surface and to disintegrate physically and chemically, beginning almost immediately and progressing over several years. What remains is a smooth implant. The half-life for biodegradation has been calculated to be about 23 months (72). Figure 9, right, shows a Replicon implant in which half of the PU coating has been shed from the surface of the implant. As these PU fragments are shed, they become integrated into the structure of the capsule, breaking up the linear nature of the collagen in the capsule. Figure 10, left, shows the linear orientation of collagen in a contracted silicone gel implant capsule. By contrast, Figure 10, right, shows that this linearity is completely broken up by the PU fragments in a capsule surrounding a PU-coated implant. Some studies have also shown that PU-inhibited fibroblasts had specific effects on immune cells (73). Other studies have noted the formation of peri-implant synovial tissue with a more cellular capsule surface (synovial metaplasia) (Figure 10, left) $(71,73,74)$. These findings are thought to reduce excessive capsular contracture. It should be emphasized that most of the published studies of the low rates of contracture were conducted over only one to three years. It is uncertain whether long term contracture results (after disintegration of the PU coating) are better than those with regular smooth implants (28). For example, significant contractures occurred late in Cohney et al's (74) large, long term study.

PU foam is also known to undergo partial chemical degradation under physiological conditions, releasing compounds that could be carcinogenic to animals. One such compound is 2,4-toluenediamine (2,4-TDA), which was shown to be toxic to a particular strain of rat $(72,75)$. This finding led to the withdrawal of PU implants from the domestic market in 1991. Subsequent reports have indicated that the very small amounts of 2,4-TDA that would be released from PU implants would not provide a significant health risk. The FDA has estimated the risk for lifetime cancer in patients with PU implants to be about five in 10 million, or about the same risk as developing cancer from smoking one cigarette (28).

\section{Other textured implants}

The success of PU implants in reducing the incidence of capsular contracture prompted many companies to develop other forms of texturing for breast implants. In 1987, McGhan developed its Biocell surface (76). This is an aggressive open-pore textured surface, similar to the PU surface. It is created using a lost salt technique. The elastomeric shell is placed on a bed of finely graded salt. Light pressure is then applied to produce depressions on the shell surface. Biocell texturing has 3.1 pores $/ \mathrm{mm}^{2}$. The pore size is 300 to $600 \mu \mathrm{m}$ and has an average height of 500 to 800 $\mu \mathrm{m}$ (28). In 1988, Mentor Corporation developed its Siltex surface, which is a shallower and less aggressive irregular surface. It is created as a negative contact imprint of a textured foam. It has surface irregularities measuring 60 to 275 $\mu \mathrm{m}$ wide and 65 to $150 \mu \mathrm{m}$ high.

Dow Corning developed its Micro Structured Implant (MSI) in 1989. This was perhaps the most scientifically developed form of surface texturing $(28,76)$. It was an extremely regular surface of projecting, minute, silicone rubber papillae created with laser technology. It had regular pillars $250 \mu \mathrm{m}$ in diameter, $750 \mu \mathrm{m}$ high and $500 \mu \mathrm{m}$ apart. This texturing was much more coarsely spaced than other implant surfaces and was easily detectable on mammography (32). These implants had a tendency to collect a thick layer of fluid between the implant and the capsule surface $(77,78)$, possibly because of the large spaces between the pillars and the added friction from the height of the pillars. The MSI Silastic implant was withdrawn from the market in 1992. The Biocell and Siltex textured surfaces continue to be used on silicone gel-filled and saline-filled implants today.

Although studies that control all variables except texturing and have adequate numbers are not available, evidence suggests that capsular contracture is less with certain textured gel implants than with smooth-surfaced implants. However, the results of published studies have not been totally convincing. Hakelius and Ohlsen (79) reported a five-year study of subglandular breast augmentation using a Biocell implant on one side and a smooth-walled implant on the other. Forty per cent of the smooth implants had capsular contracture, compared with none of the textured implants. However, there were only 25 women in that study. In 1993, Pollock (80) reviewed 197 subglandular breast augmentations. The smooth implants had a $21 \%$ incidence of capsular contracture, whereas the texturedsurface implants had only a $4 \%$ incidence. By contrast, Handel and associates (81) reported no difference in the contracture frequency between smooth implants and textured gel implants from a number of manufacturers. Similarly, Thuesen et al (82) showed no difference in capsular contracture rates among 20 women who had been giv- 
en smooth or textured implants. Some of those studies were likely affected by observer bias. Others were done over short periods of time. However, in general, it is felt that texturing of a gel implant surface results in fewer contractures than do smooth implants. It is important to stress that no such relationship has been observed with saline implants with either Biocell or Siltex texturing (83-85).

Although the rate of capsular contracture appears to be less with Biocell and Siltex gel implants than with smooth gel implants, these textured surfaces do not share the very low rate of capsular contracture seen with PU implants. This is likely due to the lack of tissue ingrowth and the lack of biodegradation of these later forms of texturing (69-71). Neither the MSI nor the Siltex textured implants induce the type of tissue ingrowth that was seen with PU texturing (25). Biocell implants can incite ingrowth, but only when the implant is under pressure, such as with class III or IV capsular contracture.

Under some circumstances, texturing can have negative effects. It can be associated with the collection of more peri-implant fluid (77), in part due to the secretion of proteoglycans by synovial secretory cells (74). The texturing can exaggerate surface wrinkling and folds by its adherence to soft tissue anteriorly. The increased thickness of the implant can make the resulting breast feel firmer. Women were said to prefer the Mentor smooth model to the often palpable and visible Siltex model (78). The shells of textured implants have been shown to be more radiopaque than the corresponding uncoated gel implants (64).

Some studies have shown that the reduction in capsular contracture seen with some textured gel implants may be related to the depth and spacing of the texturing. In some cases, almost no effects were noted if surface deformities were shallow. Brohim and colleagues (83) showed that the magnitude (height and depth) of implant texturing influences the quality of tissue ingrowth. They claimed that a pore size of $350 \mu \mathrm{m}$ was required to disrupt the formation of a continuous capsule aligned parallel to the implant surface.
Danino et al (84) compared the electron microscopic appearance of the capsules of Biocell RTV saline implants (pore size 600 to $800 \mu \mathrm{m}$ ) with those of Siltex 1600 implants (pore size 150 to $200 \mu \mathrm{m}$ ). They showed that only the Biocell capsules presented a mirror image on the capsule. This finding, indicating an adhesive effect between the shell and the capsule, seemed to be related to the larger critical size of the Biocell pores.

\section{SUMMARY}

The evolution of breast implants has been a colourful one, extending over the past 50 years. Many types of implants have come into vogue and then been discarded and replaced with newer products. Following the conclusive findings that silicone gel-filled breast implants are not related to the development of medical disease $(23,28)$, breast augmentation surgery has now become more popular than ever. In 2001, more than 217,000 women underwent breast augmentation in the United States. Currently, $95 \%$ of these patients receive saline-filled implants. Only 5\% of the implants are gel filled. As further research is conducted, and as the final results of the FDA Adjunct Study become available, the ratio of saline- to gel-filled implants will likely change. Ultimately, manufacturers will develop newer and better breast implants.

ACKNOWLEDGEMENTS: This study was funded by grants from the Medical Research Council of Canada and the Educational Foundation of the American Society of Plastic and Reconstructive Surgeons. The author is very thankful to Dr Peter Wyshynski, Waterloo, Ontario, for providing the Ashley NaturalY polyurethane implants (1969), and to Dr Jean-Luc Bergeron, Sherbrooke, Quebec, for providing the early model Simaplast implants (1969). The author expresses his deepest possible gratitude to Professor Dennis C Smith. For more than 30 years, since he was a first-year medical student, the author has done research studies with Dennis Smith. Professor Smith has always been a mentor for research and for the process of life.

\section{REFERENCES}

1. Grindlay JH, Clagett OR. Plastic sponge which acts as a framework for living tissue. Arch Surg 1951;63:288-97.

2. Pangman WJ, Wallace RM. The use of plastic prosthesis in breast plastic and other soft tissue surgery. West J Surg Obstet Gynecol 1955;63:503-12.

3. Liu LW, Truong LD. Morphologic characterization of polyvinyl sponge (Ivalon) breast prosthesis. Arch Pathol Lab Med 1996;120:876-8.

4. Glatt BS, Afifi G, Noone RB. Long-term follow-up of a sponge breast implant and review of the literature. Ann Plast Surg 1999:42:196-201.

5. Schwartz AW, Erich JB. Experimental study of polyvinyl-formal (Ivalon) sponge as a substitute for tissue. Plast Reconstr Surg 1960;25:1-14

6. Peters WJ, Smith DC. Ivalon breast prostheses: Evaluation 19 years after implantation. Plast Reconstr Surg 1981;67:514-8.

7. Edgerton MT, McClary AR. Augmentation mammaplasty: Psychiatric implications and surgical indications. Plast Reconstr Surg 1958;21:279-305.
8. Moore AM, Brown JB. Investigation of polyvinyl compounds for use as subcutaneous prosthesis (Polyvinyl Sponge, Ivalon). Plast Reconstr Surg 1952;10:453-9.

9. Conway H. Mammaplasty: Analysis of 110 consecutive cases with end results. Plast Reconstr Surg 1952;10:303-15.

10. Conway H, Smith J. Breast plastic surgery: Reduction mammoplasty and mammary construction. Analysis of 245 cases. Plast Reconstr Surg 1953;12:110-7.

11. Harris HI. Survey of breast implants from the point of view of carcinogenesis. Plast Reconstr Surg 1961;28:81-3.

12. Dukes CE, Mitchley JI. Polyvinyl sponge implants: Experimental and clinical observations. Br J Plast Surg 1962:225-8.

13. Naso A. Mastectomy and aesthetic reconstruction of the mammary region with polyethylene sponge. Rioforma Med 1953;675:662-5.

14. Conway H, Dietz GH. Augmentation mammoplasty. Surg Gynecol Obstet 1962;114:573-7.

15. Pickrell K. An evaluation of Etheron as an augmentation material in plastic and reconstructive surgery. A long-term clinical experimental study. The Annual Meeting of the American Society of Plastic and 
Reconstructive Surgery. Hawaii, October, 1962.

16. Regnault P. One hundred cases of retromammary implantation of Etheron followed up for 30 months. In: Transactions of the Third International Congress of Plastic Surgery. Amsterdam: Excerpta Medica Foundation, 1963:74

17. Regnault PC. Indications for breast augmentation. Plast Reconstr Surg 1967;6:524-9.

18. Edwards BF. Teflon silicone breast implants. Plast Reconstr Surg 1963:32:519-23

19. Smahel J, Schneider K, Donski P. Bizarre implants for augmentation mammaplasty: Long term human reaction to polyethylene strips. Br J Plast Surg 1977;30:287-90.

20. Cronin TD, Gerow FG. Augmentation mammaplasty: A new natural feel prosthesis. Transactions of the Third International Congress of Plastic Surgery. Amsterdam: Excerpta Medica Foundation, 1964:41-9.

21. Callahan T. Tensile strength and liquid silicone bleed. The United States Food and Drug Administration General Plastic Surgery Devices Panel Meeting. Bethesda, February, 1992. Transcript vol 1:73-84

22. Peters WJ, Smith D, Lugowski S. Failure properties of 352 explanted silicone-gel breast implants. Can J Plast Surg 1996;4:55-8.

23. Silicone Gel Breast Implants. The Report of the Independent Review Group. Cambridge, United Kingdom, 1998.

24. Robinson OF, Bradley EL, Wilson DS. Analysis of explanted silicone implants: A report of 300 patients. Ann Plast Surg 1995;34:1-7.

25. Peters WJ, Pritzker KP, Smith DC, et al. Capsular calcification associated with silicone breast implants: incidence, determinants, and characterization. Ann Plast Surg 1998;41:348-60.

26. Peters W. Current status of breast implant survival properties and the management of the woman with silicone gel breast implants. Can J Plast Surg 2000;8:54-67.

27. Peters W, Lugowski S. Survival properties of third-generation silicone gel breast implants. Can J Plast Surg 2002;10:109-12.

28. Bondurant S, Enester V, Herdman R, eds. Safety of Silicone Breast Implants. Institute of Medicine. Washington: National Academy Press, 1999.

29. Peters WJ, Smith DC, Lugowski S. Silicone assays in women with and without silicone gel breast implants. Ann Plast Surg 1999;43:324-30.

30. Yu LT, Latorre G, Marotta J, et al. In vitro measurement of silicone bleed from breast implants. Plast Reconstr Surg 1996;4:756-64.

31. Middleton MS. Magnetic resonance evaluation of breast implants and soft-tissue silicone. Top Magn Reson Imaging 1998;9:92-137.

32. Middleton MS. Mammary Implant Product List 1962-1968. San Diego: UCSD Magnetic Resonance Institute, 1999.

33. Submission of Rule 706 National Science Panel Report. In: re: Silicone Gel Breast Implant Products Litigation (MDL 926) (ND Ala 1998) (No CV92-P-10000 S).

34. Cook RR, Delongchamp RR, Woodbury MA, et al. The prevalence of women with breast implants in the United States - 1989. J Clin Epidemiol 1995;48:529-36.

35. Kessler DA. The basis of the FDA's decision on breast implants. N Engl J Med 1992;326:1713-5.

36. Heden P, Jernbeck J, Hober M. Breast augmentation with anatomical cohesive gel implants. Clin Plast Surg 2001;28:531-52.

37. Young LV, Lund $\mathrm{H}$, Ueda K, et al. Bleed of and biologic response to triglyceride filler used in radiolucent breast implants. Plast Reconstr Surg 1996;97:1179-93.

38. Rizkalla M, Duncan C, Matthews RN. Trilucent breast implants: A 3-year series. Br J Plast Surg 2001;54:125-7.

39. Alcaraz JB, Dominguez ED, Busquests NM, et al. Rupture of Trilucent-type breast implants: A clinical case. Aesthetic Plast Surg 2001;24:43-5.

40. McGrath MH, Burkhardt BR. The safety and efficacy of breast implants for augmentation mammoplasty. Plast Reconstr Surg 1984;74:550-60.

41. Arion HG. Presentation d'une prosthese retra mammaire. J Soc Francais Gynecol 1965:2:5-9.

42. Product Information Brochure. Simaplast Implant. Yonkers: Simaplast Inc, 1967.

43. Tabari K. Augmentation mammoplasty with Simaplast implant. Plast Reconstr Surg 1969;44:468-70.

44. Williams JE. Experiences with a large series of silastic breast implants. Plast Reconstr Surg 1972;49:253-60.

45. Koning W. Simaplast Status Report. Dow Corning internal memorandum, 118521, 1970 .
46. Wilson CA. Experiences with Arion's Simaplast inflatable prosthesis. South Med J 1969;62:1107-10.

47. Peters WJ, Smith DC, Lugowski S, et al. Simaplast inflatable breast implants: Evaluation after 23 years in situ. Plast Reconstr Surg 1999;104:1539-44.

48. Peters WJ, Smith DC, Lugowski S, et al. Calcification properties of saline-filled breast implants. Plast Reconstr Surg 2001;107:356-63.

49. Product Information Binder. Heyer-Schulte Corporation. Santa Barbara, California, 1974.

50. Trupman ES, Ellenby JD. A 13-year evaluation of subpectoral augmentation mammoplasty. In: Owsley JQ Jr, Peterson RA, eds. Symposium on Aesthetic Surgery of the Breast. St Louis: Mosby, 1978:344-52.

51. Regnault P, Baker TJ, Gleson MC, et al. Clinical trial and evaluation of a proposed new inflatable mammary prosthesis. Plast Reconstr Surg 1972;50:220-6.

52. Worton EW, Seifert LN, Sherwood R. Late leakage of inflatable silicone breast prostheses. Plast Reconstr Surg 1993;65:302-6.

53. Tebbetts JB. What is adequate fill? Implications in breast implant surgery. Plast Reconstr Surg 1996:97:1451-4.

54. Gibney J. Saline breast implant deflation rate. Plast Reconstr Surg 1996;95:1329-55

55. Gutowski KA, Mesna GT, Cunningham BL. Saline-filled breast implants: A Plastic Surgery Educational Foundation multicenter outcomes study. Plast Reconstr Surg 1997;100:1019-27.

56. Cederna JP. Partial deflation of a saline breast implant. Plast Reconst Surg 1996;97:684-5.

57. Peters W. Failure properties of leaf valve inflatable saline breast implants. Can J Plast Surg 1997;5:241-5.

58. Ashley FL. A new type of breast prosthesis. Preliminary report. Plast Reconstr Surg 1970;45:41-4.

59. Ashley FL. Further studies on the Natural Y breast prosthesis. Plast Reconstr Surg 1972;49:414-9.

60. Capossi A, Pennisi VR. Clinical experience with polyurethanecovered gel-filled mammary prostheses. Plast Reconstr Surg 1981;68:512-8.

61. Pennisi VR. Polyurethane-covered silicone-gel mammary prosthesis for successful breast reconstruction. Aesthetic Plast Surg 1985;9:73-7.

62. Pennisi VR. Long-term use of polyurethane breast prostheses: A 14year experience. Plast Reconstr Surg 1990;86:368-71.

63. Capozzi A. Long-term complications of polyurethane-covered breast implants. Plast Reconstr Surg 1991;88:458-61.

64. Young VL, Lund H, Destouet, J, et al. Effect of breast implants on mammography. South Med J 1991;84:707-14.

65. Herman S. The Meme implant. Plast Reconstr Surg 1984;73:411-3.

66. Melmed E. Polyurethane implants: A 6-year review of 416 patients. Plast Reconstr Surg 1988;82:285-91.

67. Dolsky RL. Inserting the Meme prosthesis. Plast Reconstr Surg 1984;73:466-70.

68. Vasquez G. A ten-year experience using polyurethane-covered breast implants. Aesthetic Plast Surg 2000;23:189-96.

69. Benoit FM. Degradation of polyurethane foam used in the Meme breast implant. J Biomed Mater Res 1993;27:1341-8.

70. Barone FE, Perry L, Keller T, et al. The biochemical and histopathic effects of surface texturing with silicone and polyurethane in tissue implantation and expansion. Plast Reconstr Surg 1992;90:77-83.

71. Raso DS, Greene WB. Silicone breast implants: Pathol Ultrastruct Pathol 1997:21:263-71.

72. Spear SL, Elmaraghy M, Hess C. Textured-surface saline-filled silicone breast implants for augmentation mammaplasty. Plast Reconstr Surg 2000;105:1542-54.

73. Bradley SG, Munson AE, McCay J, et al. Subchronic 10-day immunotoxicity of polydimethylsiloxane (silicone) fluid, gel and elastomer and polyurethane disks in female B6C3F1 mice. Drug Chem Toxicol 1994;176:175-220.

74. Cohney BC, Cohney TB, Hearne VA. Augmentation mammoplasty - A further review of 20 years using the polyurethane-covered prosthesis. J Long-Term Effects Med Implants 1992;1:269-79.

75. Boyes DC, Adey C, Bailar K, et al. Expert panel on the safety of polyurethane-covered breast implants. CMAJ 1991;145:1125-32.

76. Hester TR Jr, Ford NF, Gale PJ, et al. Measurement of 2,4toluenediamine in urine and serum samples from women with Meme or Replicon breast implants. Plast Reconstr Surg 1997;100:1291-8.

77. Ahn CY, Ko CY, Wagar EA, et al. Clinical significance of intracapsular fluid in patients' breast implants. Ann Plast Surg 1995;35:445-57. 
78. Burkhardt BR, Demas CP. The effect of Siltex texturing and povidone-iodine irrigation on capsular contracture around saline inflatable breast implants. Plast Reconstr Surg 1994:3:123-8

79. Hakelius L, Ohlsen L. Tendency to capsular contracture around smooth and textured gel-filled silicone mammary implants: A 5 year follow-up. Plast Reconstr Surg 1997;100:1566-72.

80. Pollock H. Breast capsular contracture: A retrospective study of textured versus smooth silicone implants. Plast Reconstr Surg 1993:91:404-10.

81. Handel N, Jensen JA, Black Q, et al. The fate of breast implants: A critical analysis of complications and outcomes. Plast Reconstr Surg 1995;96:1521-33

82. Thuesen B, Siim E, Christensen L, et al. Capsular contracture after breast reconstruction with the tissue expansion technique. A comparison of smooth and textured silicone breast prostheses. Scand J Plast Reconstr Surg 1995;29:9-13.

83. Brohim RM, Foresman PA, Hildebrandt PK, et al. Early tissue reaction to textured breast implant surfaces. Ann Plast Surg 1992;28:354-62.

84. Danino AM, Basmacioglu P, Saito S, et al. Comparison of the capsular response to the Biocell RTV and Mentor 1600 Siltex breast implant surface texturing: A scanning electron microscopic study. Plast Reconstr Surg 2001;108:2047-52.

85. Fagrell D, Berggren A, Tarpila E. Capsular contracture around saline-filled fine textured and smooth mammary implants: A prospective 7.5-year follow-up. Plast Reconstr Surg 2001;108:2108-12. 